\title{
Genetic testing and immunohistochemistry for SDHB in phaeochromocytoma-paraganglioma syndromes: the South Australian experience
}

\author{
NK Poplawski ${ }^{1,2,3^{*}}$, L Rawlings ${ }^{4}$, J Seymour ${ }^{4}$, C Vakulin $^{4}$, A Tirimacco ${ }^{4}$, DE Benn ${ }^{5}$, AJ Gill ${ }^{6,7}$ \\ From Familial Aspects of Cancer 2011 Research and Practice: A combined meeting of kConFab, Australian \\ Breast Cancer Family Study, Australian Colorectal Cancer Family Study, Australian Ovarian Cancer Study, \\ Family Cancer Clinics of Australia and New Zealand and kConFab \\ Kingscliff, Australia. 23-26 August 2011
}

\section{Aim and methods}

a retrospective review of germline genetic testing $(V H L$, $R E T$ and succinate dehydrogenase subunit genes $S D H B$, $S D H C$ and $S D H D)$ and immunohistochemical staining for SDHB in tumour tissue (SDHB-IHC), in patients referred to the South Australian Familial Cancer Unit with an adrenal phaeochromocytoma (PC) and/or paraganglioma (PGL).

\section{Results}

between January 1999 and May 2011, 24 probands were referred to and assessed by our service. The clinical presentation and mutation pick up are presented in the table. Tumour tissue was available from 20 probands and SDHB-IHC was abnormal in all probands with an SDH mutation $(5 / 5 ; 100 \%), 0 / 1$ with a $V H L$ mutation and $2 / 12(16 \%)$ with no identified mutation (the 2 probands with abnormal SDHB-IHC both presented with familial head \& neck PGL). Tissue was unavailable for testing in the remaining 4 patients; 3 with a RET mutation and a MEN2 phenotype; 1 with an SDHD mutation and familial head \& neck PGL (SDH-IHC is pending in her affected sister). Table 1.

\section{Conclusion}

our experience supports using SDHB-IHC as a tool to triage genetic testing in patients with PC or PGL.

Table 1

\begin{tabular}{|c|c|c|c|c|c|c|c|}
\hline \multirow[t]{2}{*}{ Phenotype } & \multirow[t]{2}{*}{ No. } & \multicolumn{6}{|c|}{ Number with mutation identified } \\
\hline & & Total & RET & VHL & $S D H B$ & SDHC & SDHD \\
\hline Apparently sporadic unilateral PC & $10^{\wedge}$ & 1 & - & - & $1^{*}$ & - & - \\
\hline Familial PC & 1 & 1 & - & 1 & - & - & - \\
\hline PC \& MEN2 features & 3 & 3 & 3 & - & - & - & - \\
\hline Apparently sporadic head \& neck PGL & 4 & 2 & - & - & - & 1 & 1 \\
\hline Familial head \& neck PGL & 3 & 1 & - & - & - & - & 1 \\
\hline Apparently sporadic malignant abdominal PGL & 3 & 2 & - & - & 2 & - & - \\
\hline TOTAL & 24 & 10 & 3 & 1 & 3 & 1 & 2 \\
\hline
\end{tabular}

* presented with unilateral PC and developed a head and neck PGL 14 years after the PC

$\wedge$ VHL and RET testing incomplete in 2 (complete testing will be presented at the meeting)

\footnotetext{
* Correspondence: nicola.poplawski@health.sa.gov.au

'Familial Cancer Unit, Women's and Children's Hospital, North Adelaide, SA,

Australia

Full list of author information is available at the end of the article
} 


\section{Author details}

'Familial Cancer Unit, Women's and Children's Hospital, North Adelaide, SA, Australia. ${ }^{2}$ Familial Cancer Unit, SA Pathology (WCH Site), North Adelaide, SA, Australia. ${ }^{3}$ University of Adelaide, Adelaide, SA, Australia. ${ }^{4}$ Genetics \&

Molecular Pathology Directorate, SA Pathology (Frome Road Site), Adelaide,

SA, Australia. ${ }^{5}$ Cancer Genetics, Kolling Institute of Medical Research, Royal North Shore Hospital, St Leonards, NSW, Australia. ${ }^{6}$ Department of

Anatomical Pathology, Royal North Shore Hospital, St Leonards, NSW,

Australia. ${ }^{7}$ University of Sydney, Sydney, NSW, Australia.

Published: 12 April 2012

\section{Reference}

1. Gill, et al: Hum Pathol. 2010, 41:805-14, van Nederveen et al Lancet Oncol 2009;10:764-771.

doi:10.1186/1897-4287-10-S2-A60

Cite this article as: Poplawski et al:: Genetic testing and

immunohistochemistry for SDHB in phaeochromocytoma-

paraganglioma syndromes: the South Australian experience. Hereditary

Cancer in Clinical Practice 2012 10(Suppl 2):A60.

\section{Submit your next manuscript to BioMed Central} and take full advantage of:

- Convenient online submission

- Thorough peer review

- No space constraints or color figure charges

- Immediate publication on acceptance

- Inclusion in PubMed, CAS, Scopus and Google Scholar

- Research which is freely available for redistribution

Submit your manuscript at www.biomedcentral.com/submit 